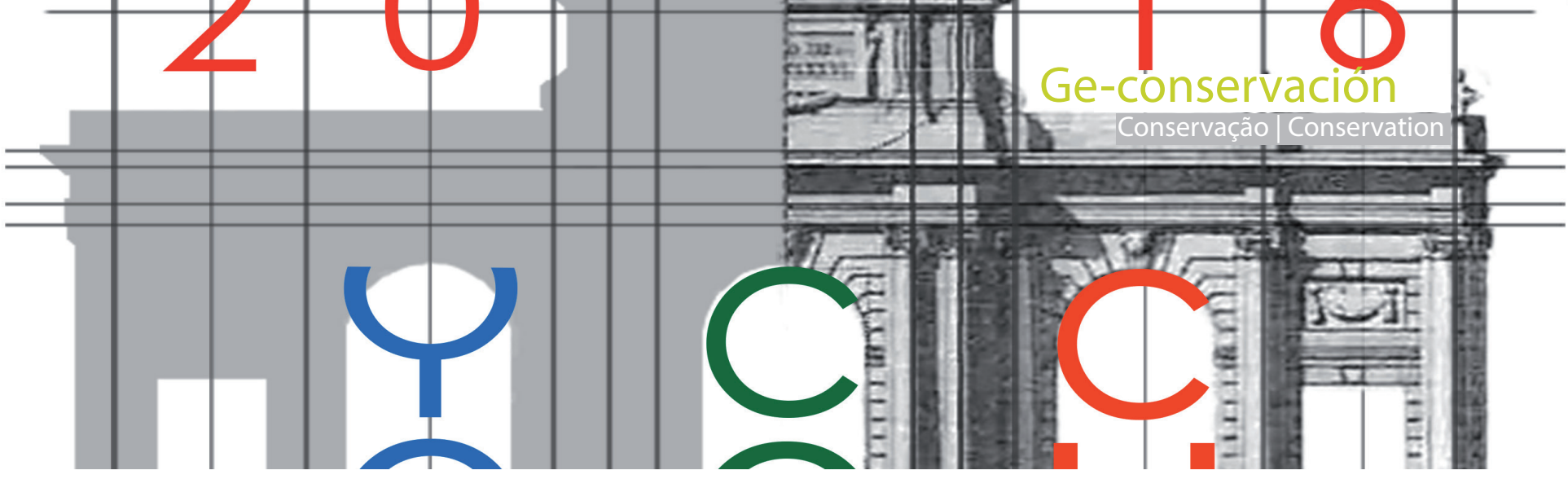

\title{
Heritage value of building materials: Former Workers Hospital of Maudes, Madrid (Spain) case study
}

\author{
Elena Mercedes Pérez-Monserrat, Rafael Fort, María José Varas-Muriel, Mónica Álvarez de Buergo
}

\begin{abstract}
Building materials used at the Former Workers Hospital of Maudes, Madrid (Spain) were studied. The study addressed the information both achieved from documental resources and characterization techniques. Documentary work has enabled to know about the architect thought, the ideology of the project or the grounds that conditioned such materials selection; it also permitted to learn about materials provenance and/or its elaboration. Analytical studies provided information about petrographic features of the materials and their composition; limestone provenance was confirmed and new data on material manufacture were provided. Such information, which deserves to be known and disseminated, provides a significant heritage value to materials that shape cultural assets. Studies with a multidisciplinary approach represent a commitment to improve the knowledge and conservation of heritage.
\end{abstract}

Key words: documental resources, analytical techniques, heritage conservation, limestone, decorative ceramics, artificial stone.

\section{El valor patrimonial de los materiales de construcción: caso de estudio en el Antiguo Hospital de Jornaleros de Maudes, Madrid (España)}

Resumen: Se estudian los materiales empleados en la construcción del Antiguo Hospital de Jornaleros de Maudes, Madrid (España). El estudio atiende a la información obtenida a partir de la consulta de fuentes documentales y del empleo de técnicas de caracterización. El análisis documental permite conocer el pensamiento del arquitecto, la ideología del proyecto o los motivos que condicionaron la selección de estos materiales, proporcionando además información sobre su procedencia y/o elaboración. El estudio analítico ofrece información sobre características petrográficas de los materiales y su composición, permite confirmar su procedencia y/o aporta nuevos datos sobre su fabricación. Este tipo de información, que merece ser conocida y difundida, otorga un importante valor patrimonial a los materiales que configuran bienes culturales. El estudio de estos materiales con un enfoque multidisciplinar supone una apuesta por el mejor conocimiento y conservación del patrimonio.

Palabras clave: fuentes documentales, técnicas analíticas, conservación patrimonio, caliza, cerámica decorativa, piedra artificial.

\section{Introduction}

This study focuses on the building materials used at the façades of the Former Workers Hospital of Maudes (Madrid, Spain), built by the Galician architect Antonio Palacios Ramilo (1874-1945) [figure 1]. Some features that characterize his work are the utilization of materials intrinsic properties, their local usage as a commitment with the identity of the places where he built and materials reuse in order to keep the costs down (González-Amezqueta 1967: $5,7-9,11,13)$.

The Former Hospital, built between 1909 and 1916 on the northern side of the city of Madrid, was conceived as a benefic institution to provide free medical care to the working class people without economical resources (Ciudad and Carrillo 2001: 13, 20). Taking advantage the healthsome breeze of the area, Palacios designed a building comprised by four wings arranged diagonally around several courtyards. The architect conferred to the property a strong hygienist and humanitarian character (Crónica e Información 1912: 1). He created a warm atmosphere by means of gardens as well as with the conjunction of lights and shades (Pérez-Rojas 1987: 115). The building was enclosed by a surrounding wall.

The façades and the wall are comprised by stonework (mainly a light-colored limestone) grouted by joint 

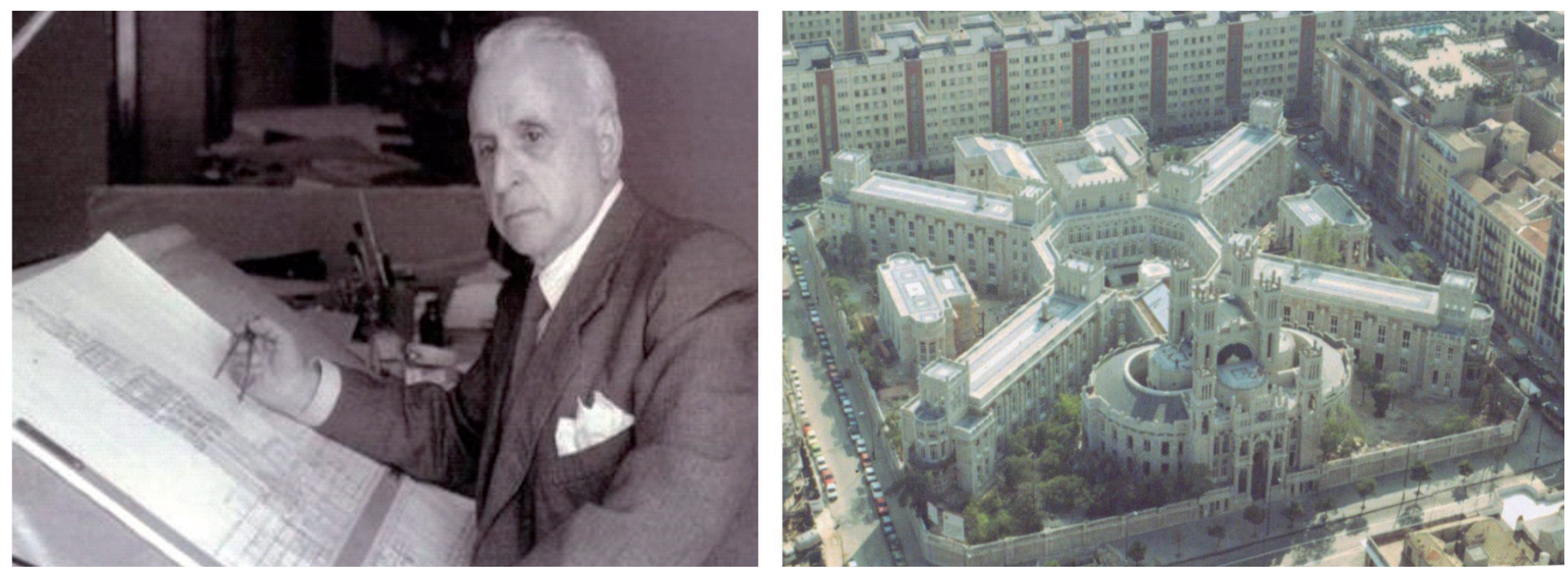

Figure 1.- Galician architect Antonio Palacios Ramilo (1874-1945) and the Former Workers Hospital of Maudes (Madrid, Spain). Images yielded by the Specialized Documents Centre of Madrid Environmental Regional Department.

mortars. Some parts of the façades are decorated with ceramic materials. A fountain is placed at the central courtyard and it is also adorned with ceramics. In some areas of the façades, artificial stone and stone imitation coatings are used. The property remained vacant between 1970-1984 years. It was listed as a National Artistic-Historic Monument in 1979 and since 1986 it houses various headquarters of the regional government of the Community of Madrid (Spain).

Two major interventions have been undertaken: a comprehensive rehabilitation in 1984-1986 (Perea 1990), and in 2006-2008, the façades restoration (Perez-Monserrat et al 2011: 298-299). Both have overall kept the message that Palacios provided to the property through the building materials used, although some original materials had to be replaced. Thereby, limestone is an original material while decorative ceramics, joint mortars, stone imitation coatings and artificial stone are both original as replaced.

The study of these building materials, taking into account the information provided by documental resources and characterization techniques, entails a valuable knowledge. Therefore, the significant heritage value of these building materials is stated and the information provided may afford more respectful interventions committed to its preservation.

\section{Methodology}

Graphic and written documentary sources related to the architectand his work, to theFormer Hospital and interventions carried out or to the provenance areas of its building materials were consulted. Besides, most of Palacios' buildings and the original quarries were visited, and materials on the Former Hospital façades were surveyed. Moreover, people linked to the Former Hospital were interviewed.

Laboratory studies were performed to characterize the building materials that shape the Former Hospital, to confirm the limestone provenance as well as to provide new data about ceramics, joint mortars, stone imitation coatings and artificial stone manufacturing.

Limestone cores were extracted directly from the façades and stone samples were taken from quarries in order to compare their macroscopic and petrographic features (GomezHeras and Fort 2004: 36). Decorative ceramics, original and replaced at the 80 s from both the façades and fountain, were characterized. Both original and replaced at 80 s artificial stone and stone imitation coatings were studied. Regarding the joint mortars, three main groups have been established from documentary sources consulted and on site visual survey: i) the original one within joints, ii) those that in 2006 were at the façades (both original or replaced at the $80 \mathrm{~s}$, before or after), as well as at the surrounding wall (built over the 60's), and iii) the joint mortar placed during the 2006-2008 restoration. Joint mortars of each group were characterized.

Minimally destructive analytical techniques were used: Polarised Optical Microscopy/POM (belonging the equipment used to the Geological Sciences Faculty of the Complutense University of Madrid, UCM), X-ray Diffraction/XRD (Microscopy and Mineralogy Unit of the Geosciences Institute, CSICUCM) and Scanning Electron Microscopy (secondary and backscattered electron -SE and BSE- images) with EnergyDispersive X-ray Spectroscopy/SEM-EDS (National Center of Electronic Microscopy of the UCM). The glazes of the decorative ceramics were also characterized by the non-destructive technique Ultraviolet-Visible Absorption Spectrophotometry/ UV-Vis, belonging to the History Institute of the Spanish Research Council (CSIC).

\section{Results and discussion}

\section{—Natural stone: a light-colored limestone}

The stonework of both the façades and the surrounding wall is made up of varied shape and size blocks of a light-colored limestone. These limestone blocks are entirely original and 
their surfaces were cleaned twice by bead blasting (at 19841986 and 2006-2008).

At the Former Hospital, the main role played by natural stone at Palacios' constructions as well as the character that he provided to the hospital are collected in the selected limestone. Therefore, a single stone type homogenizes the construction (GonzálezAmezqueta 1967: 23-24) and its lightness contributes to the warm ambience the architect intended to provide. Besides, Palacios chose a rusticated surface finishing and bossage work to highlight the natural appearance of the stone. Both resources, as well as the walls stonework design, shaped by blocks of many different volumes, also responded to the need to keep the costs down by using to the maximum the quarried stone.

Taking into account the usage of local materials that Palacios was used to, the limestone selected leads to the geological substrate of the Southeastern Community of Madrid. In that area, the carbonates from the Miocene Upper Unit of the Tertiary continental basin were traditionally exploited (Del Prado 1864: 129-131). The documents of López-Urrutia (1926: 36$)$ and the one related to the commercial promotion of Cornicabra' quarries around 1907, found at the Railway Museum of Madrid, enabled to establish in the natural area of Valhondo (Morata de Tajuña, Community of Madrid) at least one old -historical- quarry working front. In this area, the limestone quarrying was quite easy because of the scarce of sterile material to be removed. Moreover, a railway line directly connected to the city of Madrid, was just located at the bottom of the quarries. Therefore, the limestone selection was factored by the active quarries and the ways of transportation available by then in the region. Furthermore, it should be taken in mind that at the beginning of the 20th century traditional building stones used in the region were being replaced by stones from other parts of the country and even abroad (Fort et al 2002: 20). Therefore, with the limestone finally selected, Palacios was still committed with the employment of local material.

The macroscopic and petrographic (by means of POM technique) comparison of the limestone extracted from the façades and the stone samples taken from the historical quarry working front was performed. The most frequently limestone used at the façades and surrounding wall is a compact and light-colored limestone that corresponds to the homogeneous (micritic limestone) and stromatolitic-oncolytic (bioesparite) -with many molds of bioclasts such as characea algae, gastropods and stromatolitic structures- facies of the lacustrine carbonates from the Miocene Upper Unit of the Tertiary continental basin of the Southeast of the region (PerezMonserrat et al 2011:298, 301). The significant recrystallization and cementation features, typical of these carbonates (Calvo et al 1989: 285, 295; Alonso-Zarza 1992: 24, 27), reduce the primary porosity and provide a high compactness to the rock. Therefore, these carbonates entail a building material especially appropriated to withstand compression stresses and to resist water action and ageing. [figure 2]
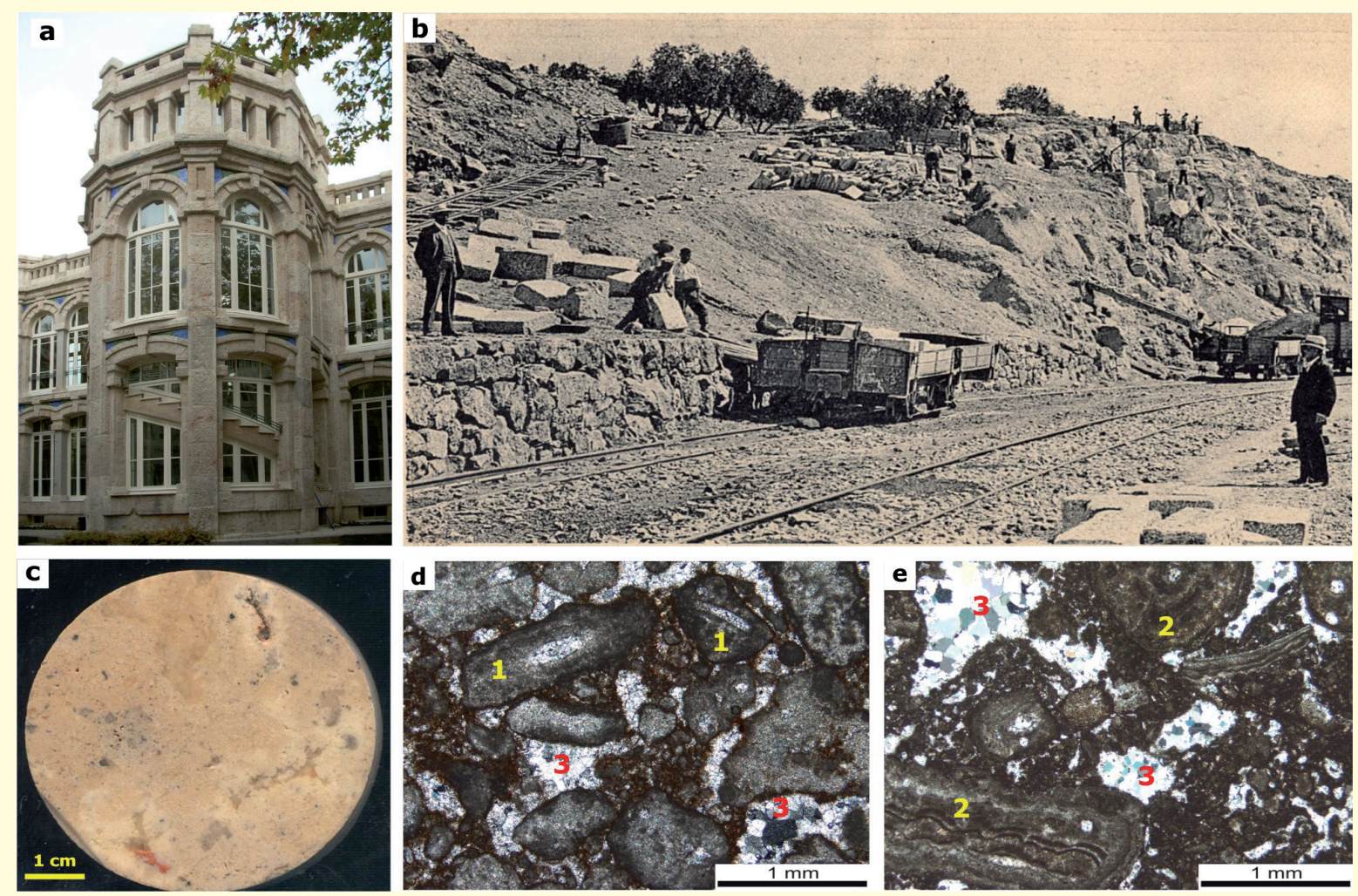

Figure 2.- Natural stone: a light-color limestone. a: façades stonework shape by limestone; b: limestone quarrying on Cornicabra'quarries at the beguining of the XX century (courtesy of the Historic Railway Archive from the Railway Museum Madrid and Spanish Railways Foundation); c: macroscopical features of the limestone used at façades (with light-color and high cementation degree); d: polarised optical micrographs of façade limestone (parallel nicols) and e: from quarry limestone (crossed nicols) -cemented characea algae (1), stromatolitic structures around characea algae sections (2) and interparticle porosity cemented and/or recrystallized (3). 


\section{_Decorative ceramics: ceramic panels and tile trencadiç}

Ceramic panels are made up by colorful tiles known as raindrop tiles, framed in a turquoise and ocher color string. The body of the fountain is decorated with similar raindrop tiles -only with a bluish tone- and its basin is adorned with a trencadiç tile (mosaic made mainly of cut and/or broken tiles and/or glass) tailored mainly by blue color pieces. Palacios used decorative ceramics in order to confer movement to façades and to enhance the pleasant atmosphere (Perla 2001: 290, 295).

At the 80 s, the original ceramic panels were almost entirely substituted, fountain raindrop tiles were preserved and the upper part of the trencadiç of the basin was partially replaced by green colored fragment of tiles. During the 2006-2008 restoration works, ceramic materials were all conserved, the colors both of the raindrop tiles and tile trencadiç were regained by wiping them and the joints between pieces were reintegrated.

Perla $(1990 ; 2001)$ provided information about the raw materials and processes used to elaborate these decorative ceramics. Original raindrop tiles and string pieces were manufactured by Daniel Zuloaga around 1914 in Segovia (Spain); iron oxide-rich red clay and silica -as an additive- were used; the pieces were fired in an oxidising atmosphere at $1200{ }^{\circ} \mathrm{C}$. Ceramic panels replaced at the 80 s were elaborated by a Madrilenian company; clays of the region, sand from Segovia and grog from Teruel were used; great amount of quartz was added; the pieces were mechanically pressed and fired under oxidising conditions at $1200-1250^{\circ} \mathrm{C}$. The original trencadiç tile of the basin of the fountain was manufactured by Sevillian and/or Eastern -from Valencia o Castellón- companies; it should be considered that the interior of the Former Hospital is decorated with ceramics processed by Ramos Rejano in Seville city, using the nearby calcium-rich clays. The tiles used to repair the trencadiç of the basin were elaborated at the Madrid's School of Ceramics with red mud, calcium-rich pastes and Madrilenian sand, by extrusion and fired at $1030^{\circ} \mathrm{C}$.

By means of POM, XRD, SEM-EDS and UV-Vis techniques, PerezMonserrat et al (2013: 489-490; 2016: 61-62) provided new data on the manufacture of these ceramic materials. Therefore, Zuloaga's pieces contain grog and quartz inclusions of very heterogeneous shape and size. A lead glaze (with circa $60 \mathrm{wt} \%$ $\mathrm{Pb}$ ) was applied. Titanium and zirconium oxides were added and the bluish tone could be achieved by means of using the Zr-V blue pigment; the uneven textural features observed by POM and SEM mainly respond to their manual processing. In the replaced panels, ceramic bodies contain a high amount of quartz inclusions; the similar size and shape of these inclusions as well as the very even texture of glazes are primarily due to the mechanised manufacturing of the replaced panels. Glazes are also leaded ( $40 \mathrm{wt} \% \mathrm{~Pb})$, zinc oxides were added and $\mathrm{Cu}^{2+}$ ions provide the turquoise color of the string pieces.

Regarding the trencadiç of the basin, the original tiles were made from calcium-rich clays, so the Sevillian company that manufactured the interior decorative ceramics could also process these tiles. The repair ones were deliberately elaborated to be stronger than the original ones, chiefly by adding more quartz inclusions and firing at higher temperatures. From the mineral paragenesis detected by $\mathrm{XRD}$, it can be inferred that original tiles were fired at temperatures higher than $800^{\circ} \mathrm{C}$ and the replaced tiles at temperatures higher than $900{ }^{\circ} \mathrm{C}$. Glazes display a heterogeneous texture with abundant particles, a lead content over $22 \mathrm{wt} \%$ was determined; $\mathrm{VI}-\mathrm{V}$ is pointed out that the blue color of original pieces is mainly due to the presence of $\mathrm{CO}^{2+}$ ions and the green color of the replaced ones is achieved by the existence $\mathrm{Co}^{2+}$ and $\mathrm{Cr}^{6+}$ ions. [figure 3]

\section{—Artificial stone, stone imitation coatings and joint mortars}

Artificial stone, stone imitation coatings and/or joint mortars are widely used at both the façades and the surrounding wall. The employment of these materials was conceived by Palacios from the beginning of the project. Indeed, the construction section of Palacios (1909) points out the use of artificial stone. On the one hand, he wanted to enrich the façades texture by applying joint mortars. On the other hand, he conceived the use of artificial stone as modernity distinctive. Besides, in some areas and mainly to avoid a costs raise, he used stone imitation coatings that imitated the limestone in color and roughness.

During the $60 \mathrm{~s}$, a very thick and straight joint mortar was applied at the external face of the surrounding wall. Later on, during the $80 \mathrm{~s}$, different interventions were performance: the artificial stone was cleaned and new artificial stone was made to replace some elements; some original stone imitation coatings were preserved -and cleaned- and others were replaced; some joint mortars were also conserved as well as cleaned, and in some areas new joint mortars were applied. In the 2006-2008 restoration, both artificial stone and stone imitation coatings were entirely preserved -they were cleaned and painted againand the joint mortars were replaced almost entirely.

Results from POM, XRD and SEM-EDS studies pointed out that the artificial stone, stone imitation coatings and joint mortars studied are mainly composed of silica and/or calcitic aggregates with lime and/or cement as binders. The detection by means of XRD and/or SEM-EDS of belite, alite and/or gehlenite mineral phases revealed if natural or artificial cement (Portland) was used. While belite and gehlenite are normally formed in natural cements, alite mineral phase defines artificial cement (Lea 1976; Callebaut et al. 2001:400, 402).

Therefore, the original artificial stone is made of natural cement and the one placed during the $80 \mathrm{~s}$ is made of lime and artificial cement. Related to the limestone imitation coatings, the original ones were made using also natural cement; those elaborated at the 80 s are constituted by aggregates obtained from the crushing of limestone and lime binder. Regarding joint mortars, original gypsum mortars within joints have been identified; the thick joint mortar that before the 2006-2008 intervention was at the external face of the surrounding wall (applied by the $60 \mathrm{~s}$ ) was made of silica aggregates and artificial cement binder. The joint mortar placed during the 2006-2008 intervention was composed of calcite aggregates and lime binder. [figure 4] 

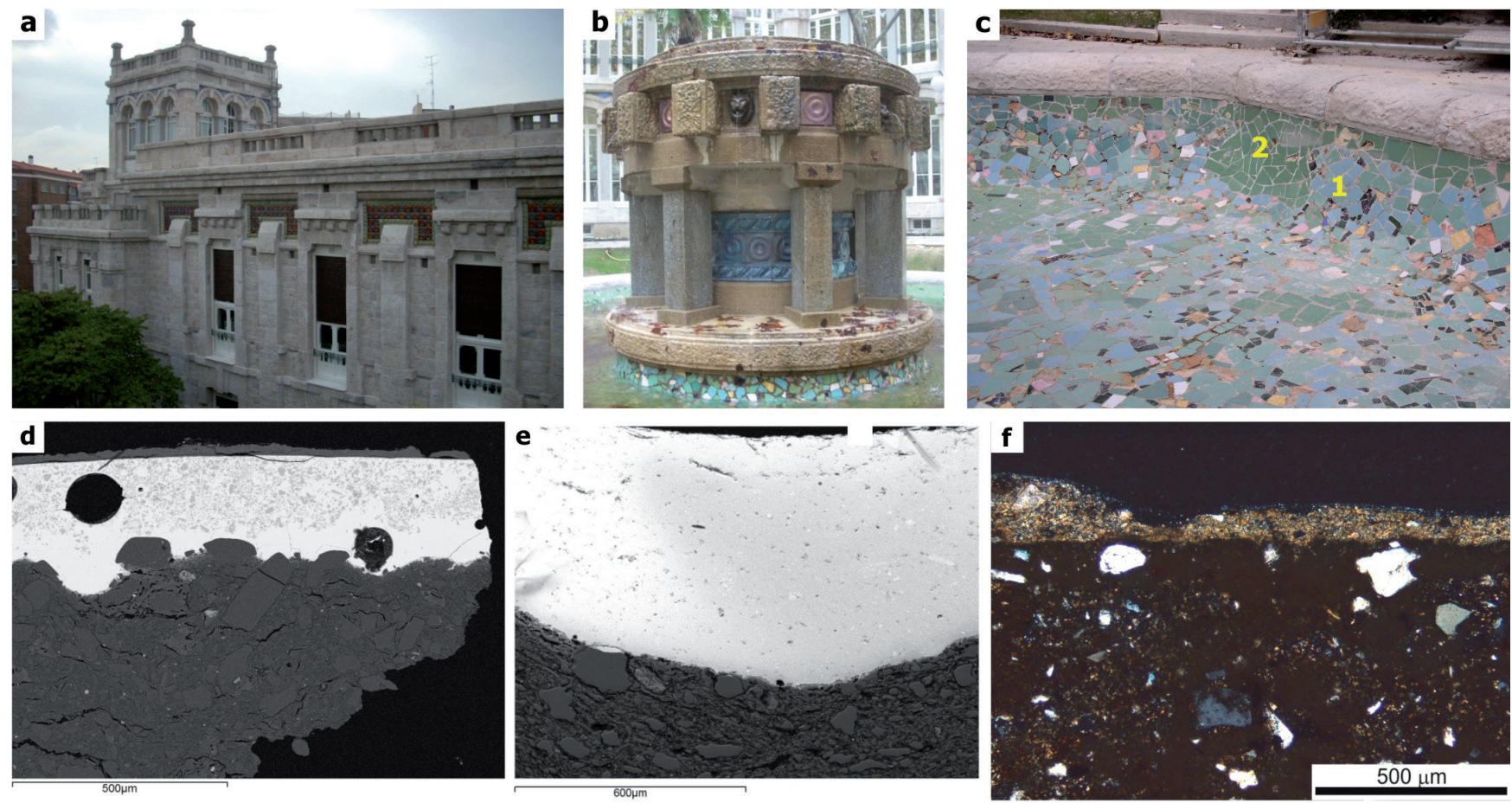

Figure 3.- Decorative ceramics: ceramic panels and tile trencadiç. a: upper part of façades decorated with ceramic panels; b: original raindrop tiles on the body of the central fountain; c: basin of the fountain adorned with tile trencadiç -original tiles (1) and tiles placed at $80 \mathrm{~s}$ (2)-; d: original tiles manufactured by Zuloaga and e: tiles elaborated at 80 s (both SEM-BSE mode images) -differences on texture and on ceramic body/glazes contact were observed-; f: polarised optical micrograph of the original tile trencadiç (crossed nicols), quartz inclusions in ceramic body and the glaze applied on the ceramic body were observed.
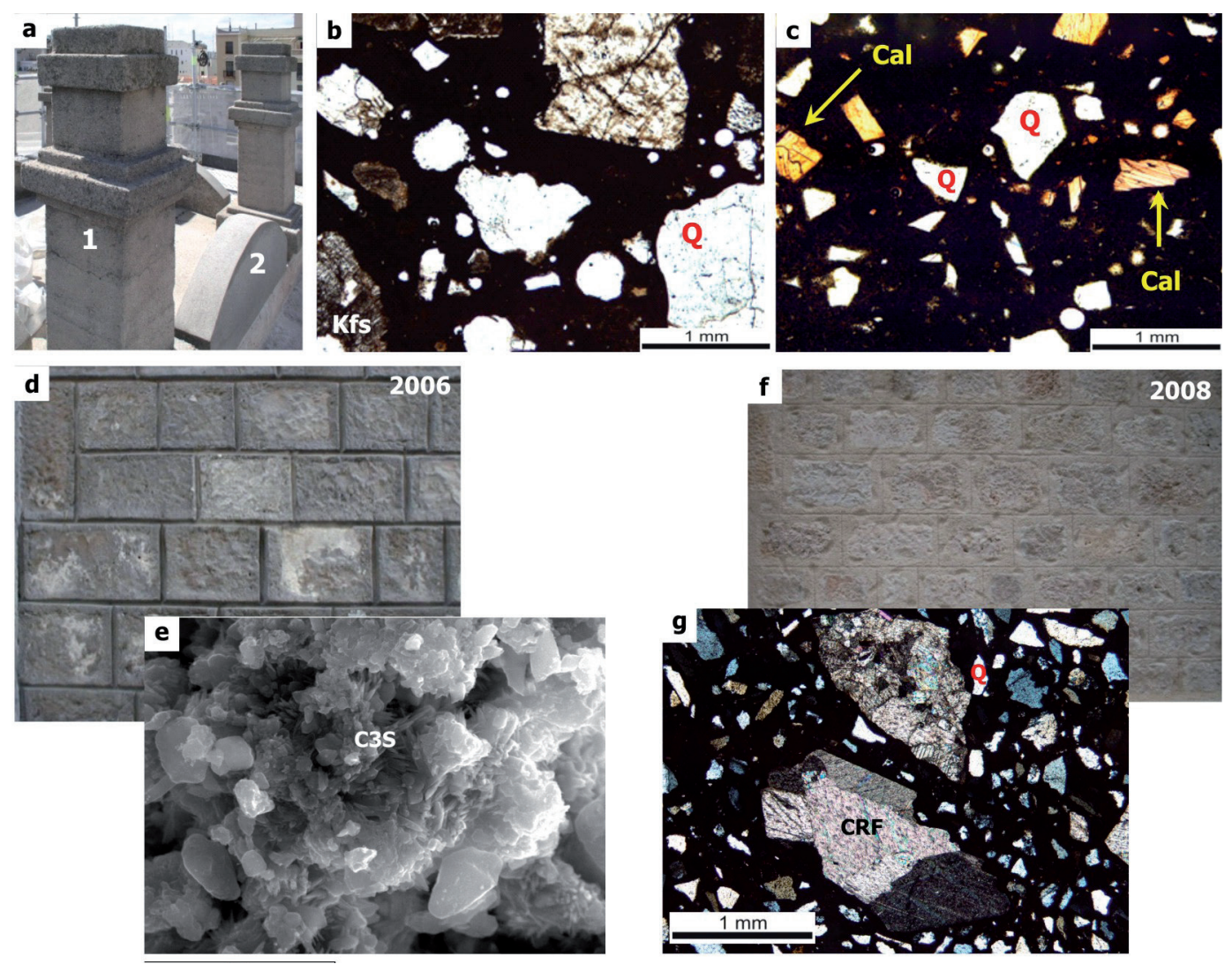

Figure 4.- Artificial stone, coatings and joint mortars. a: top construction elements made by artificial stone -original elements (1) and replaced at 80s-; b: polarised optical micrograph corresponding to original artificial stone and c: to replaced one (both crossed nicols) -quartz (Q), potassium feldspar (Kfs) and calcite (Cal)-; d: joint mortar applied at 60s and e: observed by SEM-SE mode, with alite (C3S) phase mineral presence; f: joint mortar placed in 2006-2008 restoration and g: observed by polarised optical microscopy (crossed nicols) -quartz (Q) and calcitic rock fragment (CRF)-. 


\section{Conclusions}

Regarding to the building materials used at the Former Hospital ofMaudes, the search of documentary resourcesallowed to know about the main role of natural stone at Palacios' constructions, how the limestone and ceramics participated on the message that the architect desired to provide to the property or why Palacios decided to used ceramics or artificial stone since the beginning of the project. Moreover, such resources pointed out, on the one hand, the limestone provenance in quarries located at the Southeastern of the region (Community of Madrid). On the other, that this limestone was very competitive because of its relatively easy extraction and transport by rail directly from the quarry.

The information achieved from the analytical studies permitted to confirm the provenance of the limestone and to relate its petrographic features with its good behavior as a very resistant building material. Besides, more information on raw materials and technologies used to produce decorative ceramics, both original and replaced ones, was provided. Physical and chemical data from the characterization of the artificial stone, stone imitation coatings and joint mortars were achieved. In addition, as the external joint mortars were almost completely removed in the last intervention (2006-2008), the data provided entailed a valuable document. Such knowledge pointed out a criterion for establishing whether ceramics, artificial stone, mortars and stone imitation coatings were original or not. Therefore, it would enable its new manufacturing if new replacement operations were necessary.

This study tried to entail a commitment with the better knowledge, dissemination and preservation of the building materials used in the Former Workers Hospital of Maudes, Madrid (Spain). If people in charge of these building materials conservation are aware of their heritage value, it would be much more possible to accomplish respectful interventions that may ensure the adequate conservation of the property.

\section{Acknowledgements}

The authors express their gratitude to José María la Calle, former Deputy General Director of Architecture and Urban Planning of the Community of Madrid, and José María Cabrera, managing director of the extinct Conservación del Patrimonio Artístico Company (CPA, S.A.). Technicians Marián Barajas, Iván Serrano, Xavier Arroyo, Eugenio Baldonedo and Fernando Agua are gratefully acknowledged. The authors would also like to thank the information given by Fernando de Castro López-Villarino, Antonio Perla and Andrés Perea, and the images provided by the Specialized Documents Centre of Madrid Environmental Regional Department and the Historic Railway Archive from the Railway Museum Madrid and Spanish Railways Foundation. This research was funded by Geomaterials 2 (S2013/MIT_2914) and Geomaterials (S2009/MAT_1629) Programmes, and by the Complutense University of Madrid's research group Applied Petrology for Heritage Conservation (921349). Finally, comments of the anonymous reviewers are thanked, as a better conceptual understanding of the work has been achieved.

\section{Bibliography}

ALONSO-ZARZA, A.M., WRIGHT, V.P., CALVO, J.P. AND GARCÍA DEL CURA, M.A. (1992). "Soil-landscape relationships in the middle Miocene of the Madrid Basin", Sedimentology, 39: 17-35.

CALLEBAUT, K., ELSEN, J., VAN BELEN, K. AND VIAENE, W. (2001). "Nineteenth century hidraulic restoration mortars in the Saint Michael's Church (Leuven, Belgium). Natural hydraulic or cement?". Cement and Concrete Research, 31: 397-403.

CALVO, J.P., ORDÓÑEZ, A., GARCÍA DEL CURA, M.A., HOYOS, M., ALONSO-ZARZA, A.M., SANZ, E. AND RODRÍGUEZ ARANDA, J.P. (1989). "Sedimentología de los complejos lacustres miocenos de la Cuenca de Madrid", Acta Geológica Hispana, 24: 281-298.

CIUDAD, A. AND CARRILLO, I. (2001). El Hospital de Maudes. La adaptación de un edificio a través de la historia. Madrid: Consejería de Obras Públicas, Urbanismo y Transportes de la Comunidad de Madrid.

Crónica e Información (1912). Hospital para Jornaleros en Madrid. n'16.

DEL PRADO, C. (1864). Descripción Física y Geológica de la Provincia de Madrid. Madrid: Junta General de Estadística.

FORT, R., BERNABEÚ, A., GARCÍA DEL CURA, M.A., LÓPEZ DE AZCONA, M.C., ORDÓÑEZ, S. AND MINGARRO, F. (2002). "La Piedra Novelda: una roca muy utilizada en el patrimonio arquitectónico", Materiales de Construcción, 52 (266): 19-32.

GOMEZ-HERAS, M. AND FORT, R. (2004). "Location of quarries of non traditional materials in the architecture of Madrid: the Crypt of the Cathedral of Santa María la Real de la Almudena", Materiales de Construcción, 54: 33-49.

GONZÁLEZ-AMEZQUETA, A. (1967). “La arquitectura de Antonio Palacios", Arquitectura, 106: 1-74.

LEA, F.M. (1976). The chemistry of cement and concrete. London: Edward Arnold.

LÓPEZ-URRUTIA, L. (1926). Hospital de San Francisco de Paula para Jornaleros: copia de la escritura pública del 1 de marzo de 1926 a Doña Dolores Romero y Arano. Archivo Regional de la Comunidad de Madrid, expediente $n^{\circ}$ 4259/8.

PALACIOS, A. (1909k). "El proyecto inicial". En Antonio Palacios y el Hospital de Maudes en la Memoria Arquitectónica de Madrid (1986), vol 2. Centro de Información y Documentación. Madrid: Consejería de Ordenación del Territorio, Medioambiente y Vivienda. Memoria original en el Archivo de la Villa de Madrid, expediente $n^{\circ} 20-118-3$.

PEREA, A. (1990). “El proyecto de rehabilitación". En Un Monumento recuperado: La rehabilitación del Hospital de Jornaleros de Maudes, Madrid. Madrid: Consejería de Política Territorial, Comunidad de Madrid, 25-60. 
PEREZ-MONSERRAT, E.M., VARAS, M.J., FORT, R. AND ALVAREZ DE BUERGO, M. (2011). "Assessment of different methods for cleaning the limestone façades of the Former Workers Hospital of Madrid, Spain", Studies in Conservation, 56: 298-313.

PEREZ-MONSERRAT, E.M., FORT, R., LOPEZ-ARCE. P., ALVAREZ DE BUERGO, M. AND VARAS-MURIEL, M.J. (2013). "Contribution of analytical techniques to determine the technologies used in the ceramic materials from the Former Workers Hospital of Maudes, Madrid (Spain)", Journal of European Ceramic Society, 33: 479-491.

PEREZ-MONSERRAT, E.M., PERLA, A., AGUA, F. AND FORT, R. (2016). "Intervenciones de restauración en inmuebles patrimoniales: técnicas de análisis para la diferenciación de materiales cerámicos esmaltados". En LV Congreso de la Sociedad Española de Cerámica y Vidrio, Gómez, D. (coord.). Sevilla: SECV, 61-62.
PEREZ-ROJAS, J. (1987). "Antonio Palacios y Joaquín Otamendi". En Arquitectura madrileña de la primera mitad del siglo $\mathrm{XX}$ : Palacios-Otamendi, Arbós y Anasagasti. Madrid: Museo Municipal, Ayuntamiento de Madrid, 93-175.

PERLA, A. (1990). “La Cerámica”. En Un Monumento recuperado: La rehabilitación del Hospital de Jornaleros de Maudes, Madrid. Madrid: Consejería de Política Territorial, Comunidad de Madrid, 131-161.

PERLA, A. (2001). "Antonio Palacios y la cerámica: luz y color en la arquitectura". En Antonio Palacios, constructor de Madrid. Catálogo de la exposición celebrada en Madrid. Madrid: La Librería, 289-300.

Sociedad Explotadora de las Canteras de Cornicabra (around 1907). Madrid: Archivo Histórico Ferroviario del Museo del Ferrocarril de Madrid - Fundación de los Ferrocarriles Españoles.

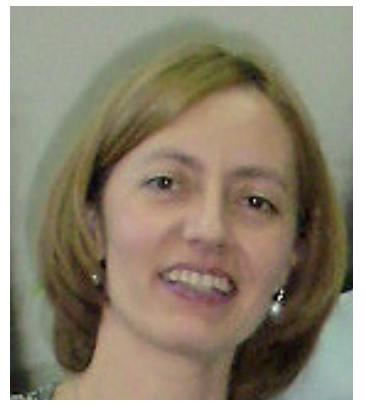

\section{Elena Mercedes Perez-Monserrat}

empmon@geo.ucm.es

Elena Mercedes Perez-Monserrat: BSc in Geology in 1999 at Complutense University of Madrid (Spain), Master's degree in Architectural and Urban Conservation in 2005 at Polytechnic University of Madrid (Spain) and PhD degree in Geology in 2015 from the UCM (Spain). She belongs to the Geosciences Institute since 2003. She has conducted many studies on the characterization, provenance and/or manufacturing and decay of built heritage materials. She develops much of her professional activity in the framework of the science management and dissemination. Address: Instituto de Geociencias IGEO (CSIC, UCM), José Antonio Nováis 12, 28040 Madrid, Spain.



\section{Rafael Fort González}

rafael.fort@csic.es

Rafael Fort: BSc in Geology in 1979 and PhD in Economic Geology in 1985, both at the Complutense University of Madrid (Spain). Since 1985 he has been studying stone material decay and the preservation techniques that can be applied to conserve the cultural heritage. He has been the responsible researcher of numerous R\&D projects and has directed many master projects and PhD. Currently, he is a senior CSIC researcher and the coordinator of the Applied Petrology for Heritage Conservation Research Group of the Geosciences Institute. Address: Instituto de Geociencias IGEO (CSIC, UCM), José Antonio Nováis 12, 28040 Madrid, Spain. 


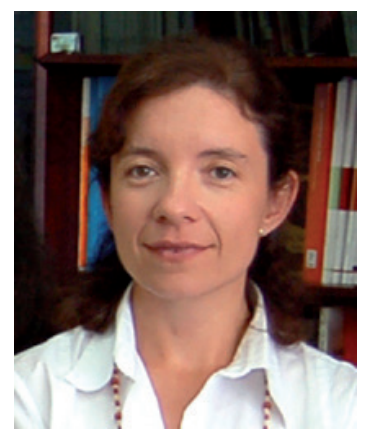

\section{Maria José Varas-Muriel}

mjvaras@ucm.es

Maria José Varas-Muriel: BSc in Geology in 1995 and PhD in 2000, both at the University of Salamanca, (Spain). Since 2001 she belongs to the Geosciences Institute, working in the field of geology applied to building materials that shape the built heritage and civil engineering constructions. Her two main of research lines are the decay caused by physical and/or chemistry incompatibility between natural and artificial materials and the decay induced by variations of indoor environmental conditions. Currently she is university lecturer at the Geology Faculty of UCM. Address: Facultad de Ciencias Geológicas, Departamento de Petrología y Geoquímica, Universidad Complutense de Madrid, José Antonio Nováis 12, 28040 Madrid, Spain.

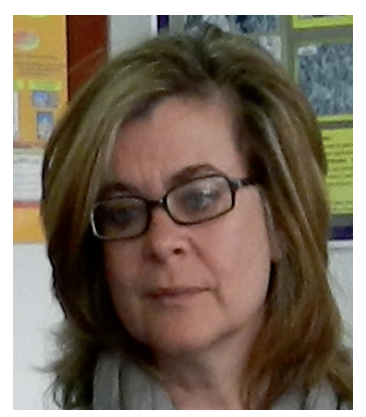

\section{Monica Alvarez de Buergo}

alvarezm@geo.ucm.es; monica.alvarez@csic.es

Monica Alvarez de Buergo: BSc and PhD degrees in Geology from the Complutense University of Madrid (Spain), in 1988 and 1994, respectively. In 1998 she joined to the Geosciences Institute, engaging in research on the preservation and decay of geomaterials of the monumental heritage. She is now a senior researcher with the Spanish Research Council (CSIC), the Head of the Geomaterials Department of IGEO and the coordinator of the Petrophysics Laboratory IGEO. Address: Instituto de Geociencias IGEO (CSIC, UCM), José Antonio Nováis 12, 28040 Madrid, Spain. 